\title{
Exercise-induced bronchoconstriction as an expression of bronchial hyperreactivity: a study of its mechanisms in children
}

\author{
HERMAN J NEIJENS, TACO WESSELIUS, KAREL F KERREBIJN \\ From the Department of Paediatrics, Subdepartment of Respiratory Diseases, Erasmus University Medical \\ School, Sophia Children's Hospital, Rotterdam, The Netherlands
}

\begin{abstract}
The mechanism of exercise-induced bronchoconstriction (EIB) was studied by observing the protective effects of several aerosol agents in a double-blind, randomised trial. Exercise-induced bronchoconstriction was not affected by placebo, but was reduced by each agent used ( $\mathrm{p}<0.001)$. Blocking the parasympathetic system had the weakest effect, while $\beta_{2}$ adrenergic stimulation produced the strongest effect which was significantly different from the parasympatholytic $(p<0 \cdot 02)$. The effect of the mast cell stabiliser, sodium cromoglycate (SCG) was found to be intermediate. However in some patients SCG had a stronger effect than the $\beta_{2}$ adrenergic agonist. A relationship was found between EIB and bronchial hyperreactivity induced by histamine $(\mathrm{p}<0.05)$.
\end{abstract}

Bronchial hyperreactivity to nonspecific stimuli is one of the hallmarks of asthma. ${ }^{12}$ This implies that bronchoconstriction occurs in asthmatics after inhalation of given concentrations of physical or chemical agents (allergens excepted) which would have no effect on healthy subjects. The degree of hyperreactivity is commonly estimated by bronchial sensitivity to histamine, acetylcholine, or methacholine. A strong correlation has been found between bronchial sensitivity to histamine and exercise-induced bronchoconstriction, ${ }^{3-5}$ and some authors $^{4}$ consider that EIB is an expression of bronchial hyperreactivity.

The mechanism of EIB is at present incompletely understood. The parasympathetic nervous system, activated by sensory fibres situated in the mucosa of the large airways ("irritant receptors") seems to play a role, because aerosolised parasympatholytic agents $^{6}$ or local anaesthetics ${ }^{7}$ may diminish or abolish EIB. Several studies ${ }^{8}$ point to the important influence of rapid ventilation with cold, dry air as the initiating stimulus which may trigger irritant receptors. $\beta_{2}$ adrenergic agonists block EIB,${ }^{6}$ which suggests that the sympathetic nervous system also plays a role. Sodium cromoglycate (SCG) often gives protection against EIB. ${ }^{9}$ This may indicate that

Address for reprint requests: Dr HJ Neijens, Department of Respiratory Diseases, Sophia Children's Hospital, Rotterdam, The Netherlands. mediator release from mast cells or from related histamine-containing cells in the bronchial lumen ${ }^{10}$ is also involved. Some authors suggest that SCG may influence EIB in other ways. ${ }^{811}$ None of these suggestions has however been substantiated, ${ }^{5}$ and we have therefore assumed that the effect of SCG is brought about by mast cell stabilisation. ${ }^{12}$

We have measured the protective effect of various agents in a group of asthmatic children who also had EIB. A $\beta_{2}$ adrenergic agonist (fenoterol), a parasympatholytic agent (oxytropium bromide) as well as a mast cell stabiliser (SCG) were all tested as aerosols. In this way the contribution of the various parts of the autonomic nervous system and of mast cells in the mechanism of EIB has been studied. The bronchial sensitivity to histamine was also measured and related to the protective effect of the agents.

\section{Methods}

The group of asthmatics studied comprised nine boys and four girls (age range: 9 to 15.5 years, mean: 12.5 years). The subjects were outpatients attending the Sophia Children's Hospital in Rotterdam. The selection criteria were: initial forced expiratory volume in one second $\left(\mathrm{FEV}_{1}\right) \geqslant 60 \%$ of the mean expected value for height and exercise-induced decrease in $\mathrm{FEV}_{1} \geqslant 15 \%$ of the initial value obtained in baseline tests on each of the three consecutive days. 
In all patients these values were reproducible - that is, their coefficient of variation (standard deviation as percentage of the mean) was less than $15 \%$. In the two weeks before the study the patients were in a stable clinical condition and had not received SCG, beclomethasone, oral corticosteroids, or $\beta_{2}$ adrenergic agonists. Other drugs were withdrawn three days before the tests.

The exercise test was done on a Jaeger treadmill following the method of Eggleston and Guerrant. ${ }^{13}$ The slope was $10^{\circ}$ and the running time about six minutes. The speed was increased to give a pulse rate of about $175 / \mathrm{min}$. This was reached at speeds between five and $12 \mathrm{~km} /$ hour.

Bronchoconstriction was detected by lung function measurements using Finivess flow-volume equipment. The $\mathrm{FEV}_{1}$ was registered by a time signal. The results were based upon the $\mathrm{FEV}_{1}$ values. The maximal expiratory flows at $25 \%$ of the forced vital capacity were also analysed but as no significant differences were found compared with the $F E V_{1}$ values they receive no further mention.

Pulmonary function tests were performed before, immediately after and $5,10,15$, and 20 minutes after completion of the exercise tests. At each time three flow-volume curves were recorded and the highest $\mathrm{FEV}_{1}$ value was taken for analysis. The change in $\mathrm{FEV}_{1}$ was expressed as a percentage of the initial value. The criterion taken for bronchoconstriction was a decrease in $\mathrm{FEV}_{1} \geqslant 15 \%$.

The study was carried out on four consecutive days. On the first day an exercise test was done after the administration of a placebo. On each of the three following days two exercise tests were performed, the first at 9 am without a protective agent (basal test). At 1040 am a protective agent was given and the second test was performed 20 minutes later. A twohour interval between tests was chosen to avoid carry-over effects. ${ }^{14}$ Although uncontrolled, the temperature and humidity of the ambient air during testing were reasonably constant at approximately $22^{\circ} \mathrm{C}$ and $70 \%$ respectively.

On each of the test days, one of the following protective agents was given in random order: oxytropium bromide (parasympatholytic), $0.02 \mathrm{mg}$ per dose aerosol (two puffs); disodium cromoglycate (mast cell stabiliser), $20 \mathrm{mg}$ as aqueous solution via ultrasonic nebuliser (Monaghan 670). The use of a solution avoided cromoglycate acting by hygroscopic effect alone; 11 fenoterol $\left(\beta_{2}\right.$ adrenergic agonist), $0.4 \mathrm{mg}$ per dose aerosol (two puffs).

The inhalation was performed as follows: after a submaximal expiration, the patient inspired synchronously with the aerosol, the mouth being kept closed over the inhaler opening. During this inspiration the tongue was kept on the floor of the mouth.
After inspiration the breath was held for five seconds. The technique was learned using a placebo. The doses were chosen to obtain a maximal pharmacological effect. ${ }^{15-17}$

The histamine threshold was determined by means of the inhalation of histamine acid phosphate in increasing concentration (doses $1,2,4,8,16,32$, and $64 \mathrm{mg} / \mathrm{ml}$ ). ${ }^{18}$ At the beginning of the inhalation each patient performed a submaximal vital capacity manoeuvre, after which they inhaled the aerosol at tidal volume for 30 seconds. The time between the inhalations was three to five minutes. The histamine concentration which caused a decrease in $\mathrm{FEV}_{1} \geqslant$ $15 \%$ of the initial value was called the histamine threshold. With this technique the histamine threshold in healthy children is $\geqslant 32 \mathrm{mg} / \mathrm{ml}$.

An analysis of variance was done in order to detect any influences of day or agent sequence on the initial $\mathrm{FEV}_{1}$ (every day at 9 am and during the day) and the decrease of the $F E V_{1}$ induced by exercise without protection (basal tests). The effects of the protective agents and comparisons between them were analysed using paired Student $t$ tests. The relationship between the decrease in $\mathrm{FEV}_{1}$ without agents and the degree of protection by each agent as well as the histamine threshold were analysed by linear regression equations from which $\mathrm{p}$ values were derived. The patient groups were divided according to the greatest effect by paired comparison between the three agents. These patient groups were compared according to initial $F E V_{1}$, decrease in FEV induced by exercise without protection and the histamine threshold. The differences were analysed by Wilcoxon tests. Five per cent was taken as the level of significance.

All patients and their parents were fully informed about the aims and nature of the study and gave their consent.

\section{Results}

In the basal tests there were no correlations between day and agent sequences on the one hand and the $\sigma$ initial FEV 1 and the decrease in $\mathrm{FEV}_{1}$ in the basal $N$ tests on the other (analysis of variance). This makes the influence of variables other than the protective agents on the results improbable. The initial FEV 1 values at 9 and 11 am did not change significantly except after the administration of the $\beta_{2}$ adrenergic $\stackrel{\oplus}{\rightleftharpoons}$ agonist when they were just significantly higher 0 $(\mathrm{p}<0.05)$.

The table shows the mean change in $\mathrm{FEV}_{1}$ after $\mathbb{D}$ exercise both with and without protection for the group as a whole. The decrease in FEV 1 without protection was $32.4 \pm 3.0 \%$ and the results after placebo did not differ significantly. After admini- 
Table Mean changes in FEV $V_{1}$ induced by exercise with and without placebo and each of the protecting agents

\begin{tabular}{|c|c|c|c|c|c|c|c|}
\hline \multirow[t]{2}{*}{ Agents used } & \multicolumn{2}{|c|}{ Decrease in $F E V_{1}$ induced by exercise } & \multicolumn{2}{|c|}{ Degree of protection $\dagger$} & \multirow{2}{*}{\multicolumn{3}{|c|}{$\begin{array}{l}\text { Difference between } \\
\text { agents } \\
p \text { value }\end{array}$}} \\
\hline & $M e a n \pm S E M$ & $p$ value & $M e a n \pm S E M$ & p value & & & \\
\hline $\begin{array}{l}\text { None } \\
\text { Placebo } \\
\text { Parasympatholytic } \\
\text { Mast cell stabiliser } \\
\beta_{2} \text { adrenergic aganist }\end{array}$ & $\begin{array}{r}-32 \cdot 4 \pm 3 \cdot 0 \\
-27 \cdot 5 \pm 3 \cdot 2 \\
-12 \cdot 5 \pm 4 \cdot 7 \\
-6 \cdot 7 \pm 2 \cdot 1 \\
+1 \cdot 5 \pm 5 \cdot 2\end{array}$ & $\begin{array}{l}\text { NS } \\
<0.001 \\
<0.001 \\
<0.001\end{array}$ & $\begin{array}{l}16 \cdot 6 \pm 4 \cdot 1 \\
25 \cdot 8 \pm 4 \cdot 1 \\
32 \cdot 5 \pm 5 \cdot 4\end{array}$ & $\begin{array}{l}<0.01 \\
<0.001 \\
<0.001\end{array}$ & $\prod_{\bullet}^{0}$ & ins & $i<0.02$ \\
\hline
\end{tabular}

Mean $\pm S E M$ are expressed as percentage of the initial values.

$\dagger$ Difference of change in FEV $_{1}$ with and without agents.

stration of the protective agents the fall in $\mathrm{FEV}_{1}$ was reduced. The changes in $\mathrm{FEV}_{\mathbf{1}}$ after each protective agent were significantly different from those without $(\mathrm{p}<0.001)$. The degree of protection, defined as the difference between the decrease in $\mathrm{FEV}_{1}$ with and without agents, was significant for each agent. When the effects of the protective agents were compared with one another significant differences were observed only between the parasympatholytic and the $\beta_{2}$ adrenergic agonist $(\mathrm{p}<0.02)$ (fig 1$)$.
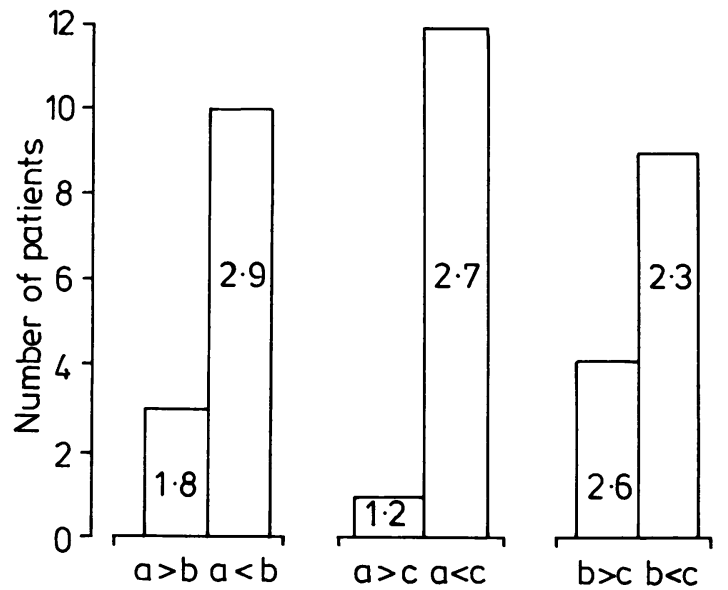

Fig 1 Number of patients according to best degree of protection in EIB by paired comparison of the agents. $a=$ parasympatholytic; $b=$ mast cell stabiliser; $c=\beta_{2}$ adrenergic agonist. The difference in effect is expressed for each patient as the quotient of the degree of protection by the agents compared. The medians of the quotients are shown in the columns.

A check was made to see if individual patients reacted differently from the group as a whole. For each patient the protective agent which gave the best degree of protection was determined by paired comparison between the agents (fig 2). The parasympatholytic gave better protection in three patients by comparison with the mast cell stabiliser and in one patient when compared with the $\beta_{2}$ adrenergic agonist. The mast cell stabiliser gave better protection than the $\beta_{2}$ agonist in four patients.

For each patient differences in protective effect were expressed in quantitative terms as the quotient of the degree of protection of the agents compared. Nearly all quotients are markedly greater than 1 , indicating that the differences in degree of protection are relevant. In fig 2 decrease in $F E_{1}$ induced by exercise without protection is compared with degree of protection afforded by the parasympatholytic and the mast cell stabiliser. The cumulative degree of protection of both agents equates with exercise induced fall in $\mathrm{FEV}_{1}$ (difference less than $10 \%$ ) in nine patients and exceeds it in the remaining four patients. Figure 2 also shows great individual differences between the cumulative degree of protection given by the parasympatholytic and mast cell stabiliser and the degree of protection given by the $\beta_{2}$ adrenergic agonist.

Figure 3 shows that the relationship between the decrease in $F E V_{1}$ induced by exercise without protection and the histamine thresholds is significant $(\mathrm{p}<0.05)$. No relationship could be detected between the decrease in $F E V_{1}$ induced by exercise and the initial $\mathrm{FEV}_{1}(\mathrm{r}=0.40$, not significant).

In fig 4 the patients are grouped according to the agent which gave the best protection by paired comparison. No significant differences between the groups existed in the initial $F E V_{1}$, decrease in $F E V_{1}$ after unprotected exercise or histamine thresholds (Wilcoxon tests).

\section{Discussion}

In this study the protective effects of a parasympatholytic, a mast cell stabiliser (SCG) and a $\beta_{2}$ adrenergic agonist on EJB were found to be significant. It is assumed that maximal bronchodilatation was achieved by the doses used and that the same was true for the protective effect on EIB although this remains unproven. Although the time between administration of the parasympatholytic and the exercise test was a little short and bronchodilatation might have occurred during the recovery 


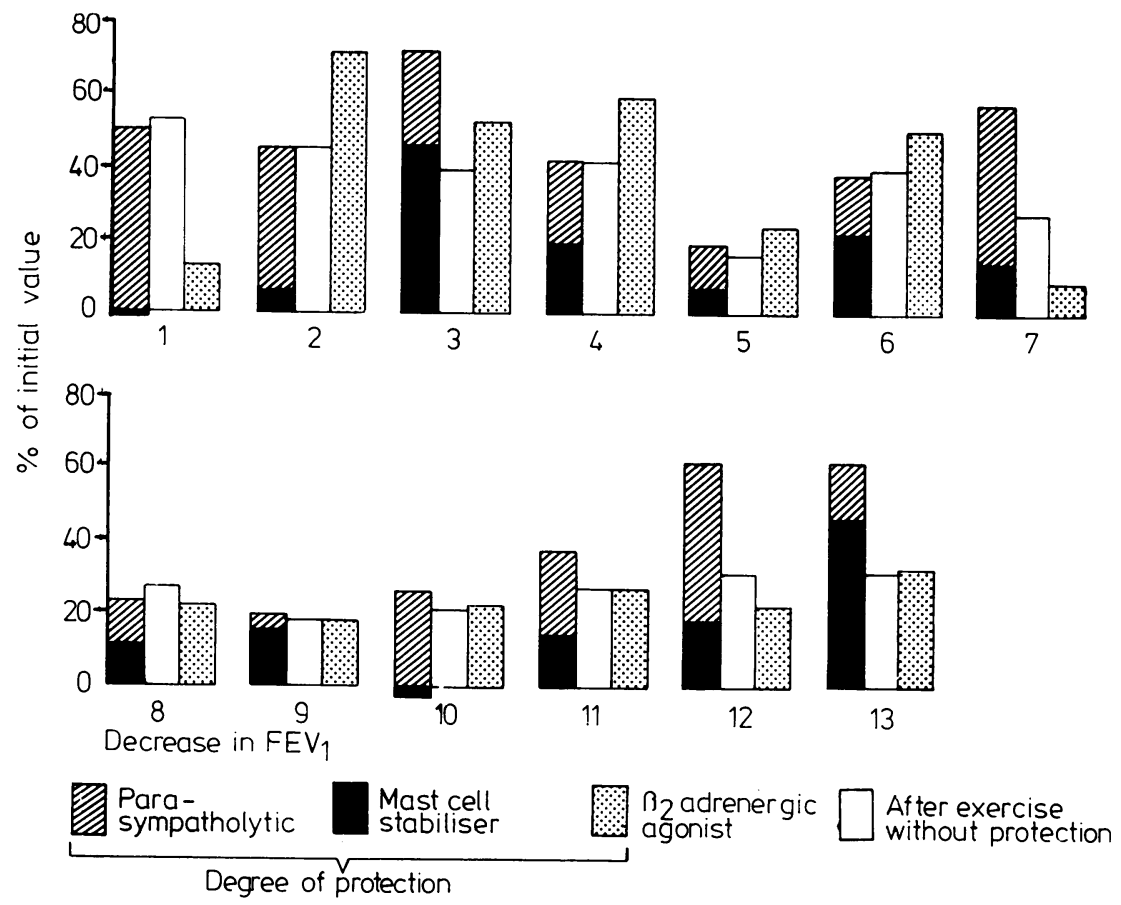

Fig 2 Degree of protection in EIB in the 13 patients given by the parasympatholytic aru the mast cell stabiliser, illustrated as cumulative effects, compared with that of the $\beta_{2}$ adrenergic agonist and the exercise-induced decrease in FEV $V_{1}$ without protection. Both degree of protection and decrease in FEV $V_{1}$ are expressed in percentages of the initial FEV $V_{1}$.

phase, we do not think this could have influenced the results significantly. The results were not influenced by variables other than the protective agents used and they are in accordance with those of other authors. ${ }^{6} 1920$

Individual patients differed in their responses to the various agents used. From the finding in some patients that the degree of protection given by the parasympatholytic exceeded that given by the mast cell stabiliser, it may be concluded that in these subjects activation of the vagus is more important than activation of the mast cell system. In contrast to the results of the patient group in general, some patients attained a greater degree of protection from the mast cell stabiliser than from the $\beta_{2}$ adrenergic agonist. In these patients it can be assumed that mediator release from mast cells is relatively important in the mechanism of EIB. It seems that blocking of histamine release from their mast cells by triggering the $\beta_{2}$ adrenergic receptors is only of limited value in contrast to the effect of SCG. Also, $\beta_{2}$ adrenergic relaxation of their bronchial muscles is of relatively little importance in the blocking of the EIB response. Although this might indicate hyporesponsiveness of their $\beta_{2}$ adrenergic receptors, this is unlikely because the bronchodilatation induced by the $\beta_{2}$ adrenergic agonist under resting conditions in these patients was not less than in the others.

Our finding of a relationship between the degree of protection given by the parasympatholytic together $x$ with the mast cell stabiliser and the degree of bronchoconstriction without protection can be explained in two ways. Firstly, a combined mechanism involving both the parasympathetic nervous system and mast cells may operate in EIB. It was not 음 possible to predict which was the dominant system

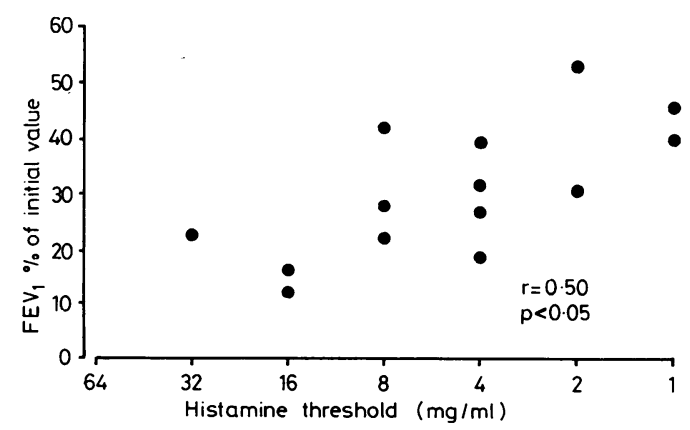

Fig 3 Relationship between the histamine threshold and the exercise-induced decrease in FEV . 


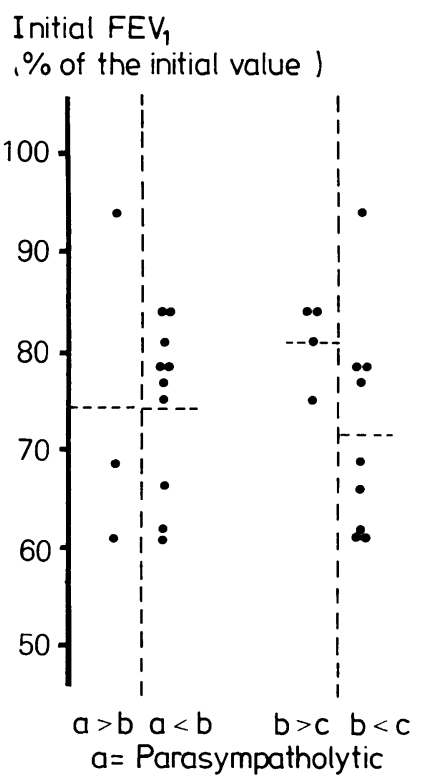
Decrease in $\mathrm{FEV}_{1}$ after
exercise without protection
$(\%$ of the initial value)

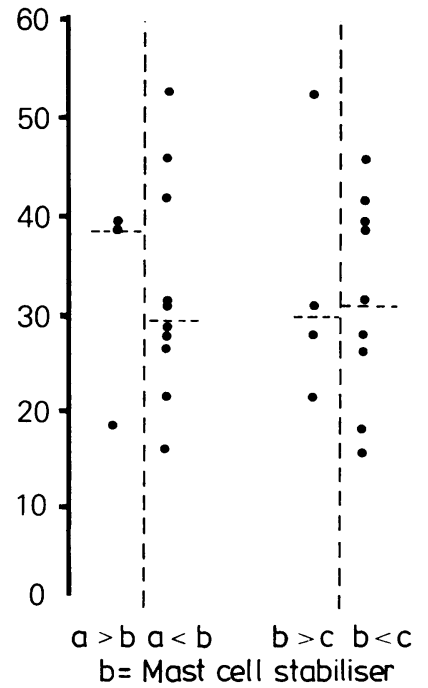

Histamine threshold $(\mathrm{mg} / \mathrm{ml})$

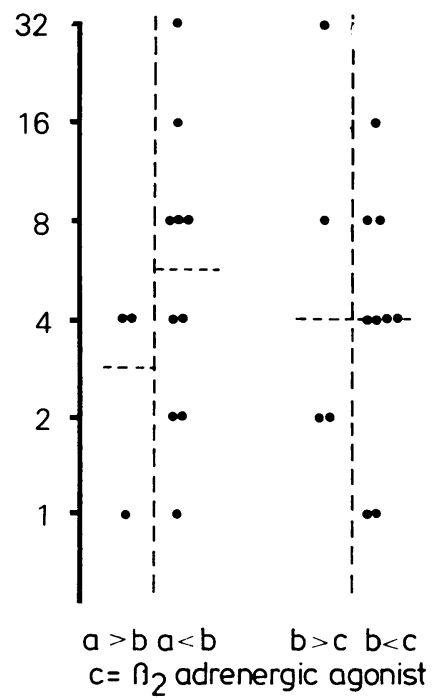

Fig 4 Initial $F E V_{1}$, decrease in FEV $V_{1}$ after exercise without protection, and histamine threshold in patient groups divided according to the best protection in EIB by paired comparison of the agents. $a=$ parasympatholytic, $b=$ mast cell stabiliser, $c=\beta_{2}$ adrenergic agonist, ----- = median. Differences between groups are not statistically significant.

from the initial lung function values, the bronchodilatation induced by the agents without exercise or the bronchial sensitivity to histamine. McFadden et $a l^{21}$ were also able to distinguish subgroups in their population with EIB and this may well be relevant to the choice of therapeutic agent. Secondly, a complete stabilisation of the mast cell, resulting in blocking of mediator release, may only occur if in addition to cromoglycate sensitive receptors the parasympathetic receptors of the mast cell are blocked as well. If it turns out that cromoglycate has effects outside mast cells then the interpretation of blocking studies such as ours will have to be reviewed. The blocking effect of cromoglycate might then be explained in part by an action on bronchial smooth muscle or irritant receptors. The important place of the mast cells in EIB is however supported by the observations that EIB is followed by a period of latency ${ }^{14}$ and that several authors ${ }^{22} 23$ have found a rise in arterial histamine concentration after exercise.

The degree of bronchoconstriction induced by exercise has a strong relationship with the bronchial sensitivity to histamine as shown in this and other studies. $^{45}$ This suggests that the mechanisms induced by both stimuli may be related. There is no difference in bronchial sensitivity to histamine in patients with EIB in whom the autonomic nervous system dominates compared with those in whom mast cells are of major importance. Thus one might suspect that both these systems play a role in the mechanism leading to bronchoconstriction after histamine inhalation. Although the reaction to histamine could be confined to the direct stimulation of the histamine receptors of the bronchial muscle cells, ${ }^{24}$ this is probably not the case. Jackson et $\mathrm{al}^{25}$ showed in rats that the autonomic nervous system was stimulated by the histamine aerosol, since the bronchial response decreased after dissection of the vagus nerve. The study of Dixon et $a^{26}$ indicates that this may be caused by stimulation of irritant receptors. It seems probable that histamine-induced vagal stimulation also triggers mast cells, because the mast cell stabiliser SCG diminishes the bronchial response to histamine in some patients. ${ }^{27} 28$

The mechanisms by which histamine and exercise induce bronchoconstriction are similar and this justifies the view that EIB can be regarded as an expression of bronchial hyperreactivity.

We would like to thank Jeannette Boogaard, Ineke Strik, Edith Bonzet, and Joke Mazee for their technical assistance. This study was supported by the Dutch Asthma Fund (project no 279) and Boehringer Ingelheim Ltd, Haarlem who also supplied the drugs. 


\section{References}

${ }^{1}$ Orehek J, Gayrard P, Smith AP, Grimaud C, Charpin J. Airway response to carbachol in normal and asthmatic subjects. Am Rev Respir Dis 1977;115:937-43.

${ }^{2}$ Cockcroft DW, Killian DN, Mellon JJA, Hargreave FE. Bronchial reactivity to inhaled histamine, a method and clinical survey. Clin Allergy 1977;7:235-43.

${ }^{3}$ Neijens HJ, Degenhart HJ, Raatgeep HC, Kerrebijn KF. The correlation between increased reactivity of the bronchi and of mediator releasing cells in asthma. Clin Allergy 1980;10:535-9

${ }^{4}$ Kiviloog J. Variability of bronchial reactivity to exercise and methacholine in bronchial asthma. Scand $J$ Respir Dis 1973;54:359-68.

${ }^{5}$ Mellis CM, Kattan M, Keens TG, Levison H. Comparative study of histamine and exercise challenges in asthmatic children. Am Rev Respir Dis 1978;117:911-5.

- Godfrey S, König P. Inhibition of exercise-induced asthma by different pharmacological pathways. Thorax 1976; $31: 137-43$.

${ }^{7}$ McNally JF, Enright P, Hirsch JE, Souhrada JF. The attenuation of exercise-induced bronchoconstriction by oropharyngeal anaesthesia. Am Rev Respir Dis 1979; 119:247-52.

${ }^{8}$ McFadden ER, Ingram RH. Exercise-induced asthma. Observations on the initiating stimulus. $N$ Engl $J$ Med $1979 ; 301: 763-9$.

${ }^{9}$ Davies SE. Effect of disodium cromoglycate on exerciseinduced asthma. $\mathrm{Br}$ Med J 1968;3:593-4.

${ }^{10}$ Patterson R, McKenna JM, Suszko IM et al. Living histamine-containing cells from the bronchial lumens of humans. J Clin Invest 1977;59:217-25.

1 McFadden ER, Ingram RH. Sites of airways responses in asthma. In: Sadoul P, Milic-Emili J, Simonsson BG, Clark TJH, eds. Small airways in health and disease. Amsterdam: Exerpta Medica, 1979:156-60.

12 Cox JSG. Disodium cromoglycate mode of action and its possible relevance to the clinical use of the drug. Br J Dis Chest $1971 ; 65$ :189-204.

${ }^{13}$ Eggleston PA, Guerrant JL. A standardized method of evaluating exercise-induced asthma. $J$ Allergy Clin Immunol 1976;58:414-25.

${ }^{14}$ Edmunds AT, Tooley M, Godfrey S. The refractory period after exercise-induced asthma its duration and relation to the severity of exercise. Am Rev Respir Dis 1978;117: 247-54.

${ }^{15}$ Altounyan REC. Inhibition of experimental asthma by a new compound-disodium cromoglycate "Intal". Acta Allergol 1967;22:487.

${ }^{16}$ Meier J. Dosis- und Zeitwirkungsuntersuchungen mit
Ipratropiumbromid und placebo bei chronischer Bronchitis und Asthma bronchiale. Wien Med Wochenschr 1974;124 suppl no $21: 29-33$.

${ }^{17}$ Stanescu D, van Lemputten R, Frans A, Brasseur L. Evaluation of lung function indices for bronchodilator trials. Results of a cross-over study of fenoterol. Respiration 1976;33:1-8.

${ }^{18}$ Devries K, Booij-Noord H, Goei Het al. Hyperreactivity of the bronchial tree to drugs, chemical and physical agents. In: Orie NGM, Sluiter HJ, eds. Bronchitis II Second International Symposium. Assen: Royal Vangorcum, 1964:167-80.

10 Tashkin DP, Katz RM, Kerschnar H, Rachelefsky GS, Siegel SC. Comparison of aerosolized atropine, isoproterenol, atropine plus isoproterenol, disodium cromoglycate and placebo in the prevention of exercise induced asthma. Ann Allergy 1977;39:311-7.

${ }^{20}$ Chan-Yeung M. The effect of Sch 1000 and disodium cromoglycate on exercise-induced asthma. Chest 1977 ; 71:320-3.

${ }^{21}$ McFadden ER, Soter NA. A search for chemical mediators of immediate hypersensitivity and humoral factors in the pathogenesis of exercise-induced asthma. In: Lichtenstein LM, Austen KF, eds. Asthma, physiology, immunopharmacology and treatment. New York: Academic Press, 1977:351-64.

${ }^{22}$ Ferris L, Anderson SD, Temple DM. Histamine release in exercise-induced asthma. $\mathrm{Br}$ Med J 1978;1:1697.

${ }^{23}$ Charles TJ, Hartley JPR, Seaton A, Taylor WH, Westwood A. Arterial histamine in exercise-induced asthma. Clin Sci $1979 ; 56: 8 \mathrm{p}-9 \mathrm{p}$.

${ }^{24}$ Fleisch JH, Kent KM, Cooper T. Drug receptors in smooth muscle. In: Austen KF, Lichtenstein LM, eds. Asthma, physiology, immunopharmacology and treatment. New York: Academic Press, 1973:139-67.

25 Jackson DM, Richards IM. The effects of sodium cromoglycate on histamine aerosol-induced reflex bronchoconstriction in the anaesthetized dog. $\mathrm{Br} J$ Pharmacol 1977;61:257-62.

${ }^{26}$ Dixon M, Jackson DM, Richards IM. The effects of histamine, acetylcholine and 5-hydroxytryptamine on lung mechanics and irritant receptors in the dog. $J$ Physiol 1979;287:393-403.

${ }^{27}$ Kerr JW, Govindara JM, Patel KR. Effect of alphareceptor blocking drugs and disodium cromoglycate on histamine hypersensitivity in bronchial asthma. $\mathrm{Br} \mathrm{Med} \mathrm{J}$ $1970 ; 2: 139-41$.

28 Woenne R, Kattan M, Levison H. Sodium cromoglycateinduced changes in the dose-response curve of inhaled methacholine and histamine in asthmatic children. $\mathrm{Am}$ Rev Respir Dis 1979;119:927-32. 